\title{
Abscess Caused by Streptococcus Constellatus Secondary to Tooth Decay on Facial Skin: Case Report
}

\author{
Diş Çürümesine İkincil Olarak Yüzde Gelişen Streptococcus Constellatus'un Neden Olduğu Apse: \\ Olgu Sunumu
}

\author{
Önder KILIÇASLAN ${ }^{1}$ \\ (D) 0000-0002-9311-006X \\ Didem KIZMAZ İŞANÇLI ${ }^{1}$ \\ (D) 0000-0002-0791-5903 \\ Esmanur FÍL ${ }^{2}$ \\ (1) 0000-0002-2419-1142 \\ Ecem ERTÜRK UZUNDAL ${ }^{2}$ \\ (D) 0000-0003-1534-1855 \\ Adem KARBUZ ${ }^{1}$ \\ (D) 0000-0002-5460-3638
}

\begin{abstract}
A six-year-old male patient with no known history of disease was presented due to an unfamiliar Streptococcus constellatus growth that developed alongside a tooth abscess and fistulized. The patient was admitted with redness, swelling, and tenderness in the left-most section of his face. We learned that the patient visited a dentist three weeks prior due to complaints of swelling in the jaw and tooth decay. The patient had a leukocyte count of $22,600 / \mu \mathrm{L}$ (neutrophil: $17,190 / \mu \mathrm{L}$ ), C-reactive protein level was $105.2 \mathrm{mg} / \mathrm{L}$. The patient was put on an intravenous treatment of clindamycin and cefoperazone-sulbactam. There was spontaneous discharge in the abscess. S. constellatus grew in abscess culture dish. The current therapy was changed to ampicillin-sulbactam. Observations on the seventh day of hospitalization showed that the lesion had subsided almost entirely. S. constellatus is a rare microorganism that produces abscesses and requires immediate medical attention.

Keywords: Abscess; child; Streptococcus milleri; Streptococcus constellatus; tooth decay.
\end{abstract}

\section{ÖZ}

Bilinen bir hastalık öyküsü olmayan altı yaşında bir erkek hasta, diş absesine ikincil gelişen ve fistülize olan cilt apsesinden alınan mikrobiyolojik incelemede alışı olmadığımız bir etken olan Streptococcus constellatus üremesi sebebiyle sunuldu. Hasta yüzün sol yarısında izlenen kızarıklık, şişlik ve hassasiyet ile başvurdu. Hastanın üç hafta önce çenede şişlik ve diş çürüğü şikayetleri ile diş hekimine gittiği öğrenildi. Lökosit sayısı 22.600/ $\mu \mathrm{L}$ (nötrofil: 17.190/ $\mu \mathrm{L}$ ), C-reaktif protein $105,2 \mathrm{mg} / \mathrm{L}$ idi. Hastaya intravenöz klindamisin ve sefoperazon-sulbaktam tedavisi başlandı. Apse kendiliğinden drene oldu. Kültürde S. consellatus üredi. Mevcut tedavi ampisilin-sulbaktam ile değiştirildi. Yatışının yedinci gününde lezyonun neredeyse tamamen gerilediği görüldü. S. constellatus nadir görülen ancak yol açtığı apseler nedeniyle dikkat edilmesi gereken bir mikroorganizmadır.

Anahtar kelimeler: Apse; çocuk; Streptococcus milleri; Streptococcus constellatus; diş çürügüü.

\section{INTRODUCTION}

Streptococcus constellatus belongs to the Streptococcus milleri group (SMG) along with Streptococcus intermedius and Streptococcus anginosus (1). They are commonly found in oropharyngeal and gastrointestinal flora. However, they can produce abscesses in the abdominal cavity, lower respiratory tract, urogenital system, orofacial area, sinuses, and skin. They are capable of hematogenous spreading, potentially causing endocarditis or metastatic abscesses in the brain, liver, spleen, 
subdural space, and bones (2). They can be characterized by their tendency to produce abscesses (3). We present a six-year-old male patient with no known history of disease who developed a fistulized skin abscess alongside a dental abscess. S. constellatus was isolated in microbiological examinations as an uncommon pathogen. This case is presented as a literary contribution as a reminder of the possibility to isolate $S$. constellatus from skin abscesses.

\section{CASE REPORT}

A six-year-old male patient with no known disease history is presented with redness, swelling, and tenderness on the left-most section of his face (Figure 1). We learned that the patient visited a dentist three weeks prior due to complaints of swelling in the jaw and tooth decay. The patient received oral amoxicillin-clavulanic acid therapy for two weeks, with a one-week follow-up without any antibiotic treatment. However, he was admitted to hospital due to a worsening conditions. We were made aware by the patient's family that he could not receive the prescribed daily-dose of antibiotics due to his oral intake problems. Upon physical examination, we observed swelling, redness, and tenderness extending from the eye to the mandible of the left-most section of the patient's face. Further examinations revealed no pathological findings. The patient did not have a fever. A purulent discharge excreted from the lesion upon direct palpation. The abscess was drained and samples were submitted to the laboratory for culture tests and Gram-staining (Figure 2). The patient's blood tests revealed a leukocyte count of $22,600 / \mu \mathrm{L}$, an absolute neutrophil count of $17,190 / \mu \mathrm{L}$, hemoglobin levels were $12.5 \mathrm{~g} / \mathrm{L}$, a platelet count of $515,000 / \mu \mathrm{L}$, and C-reactive protein levels of $105.2 \mathrm{mg} / \mathrm{L}$. There were no significant findings on the computed tomography (CT) brain scans. Orbital CT scans revealed an edematous appearance in the skin and subcutaneous tissues anteriorly at the level of the left orbit. We identified an increase of soft tissue densities subcutaneously in that area. The patient was examined by an ophthalmologist. No pathological findings were found other than preseptal cellulitis. The patient was diagnosed with "preseptal cellulitis and fistulized skin abscess secondary to a dental abscess" and was admitted to the pediatric infectious diseases inpatient clinic. Blood samples were collected for culture tests, and the patient was put on an intravenous treatment of clindamycin and cefoperazone-sulbactam. Gram-staining of samples revealed polymorphonuclear leukocyte and a moderate density of gram-positive cocci distribution. By the third day of hospitalization, $S$. constellatus had grown in the abscess cultures. So, the current therapy was changed to ampicillin-sulbactam. There were no signs of growth in the blood culture tests. During patient follow-up, it was observed that the facial swelling, redness, and tenderness had subsided almost entirely by the seventh day of antibiotic treatment (Figures 3, 4). The patient was discharged from the hospital with advice given to the patient's family.

\section{DISCUSSION}

The SMG includes the S. constellatus, S. anginosus, and $S$. intermedius species. These Gram-positive, catalase-negative cocci are predominantly commensals isolated from the oropharynx, gastrointestinal and urogenital tracts (4). However, they can attain pathogenic characteristics and cause pyogenic infections in the central nervous system, abdominal cavity, odontogenic infections, deep neck infections, endocarditis, and abscess formation. The reasons for this remain unclear. S. constellatus is reportedly associated with diseases such as Lemierre's syndrome, odontogenic cerebral abscesses, cavernous sinus thrombosis orbital cellulitis, and necrotizing orbital cellulitis. Moreover, there has been a case of S. constellatus reportedly causing chronic osteomyelitis in a patient with Cogan's syndrome, an autoimmune disease. Further studies show that $S$. constellatus caused vertebral osteomyelitis in a patient with an atrial septal defect and an odontogenic infection (5). Similarly, our patient visited the dentist due to tooth decay and subsequent dental abscess, meaning odontogenic pathology.

In a study investigating infections associated with $S$. constellatus in children, the patients' age range was found to be between 3-15 years-of-age and predominantly male. Of those patients, $56.8 \%$ did not have a fever, while $62 \%$ developed leukocytosis (6). Consistent with the aforementioned study, our patient was a six-year-old male. Fever was not present before or during the hospital admission. Tests in blood samples revealed leukocytosis $(22,600 / \mu \mathrm{L})$. In the study conducted by Clarridge et al. (3) S. constellatus was reported as the causative organism of abscesses in 41 of the 54 samples $(76 \%)$ collected from

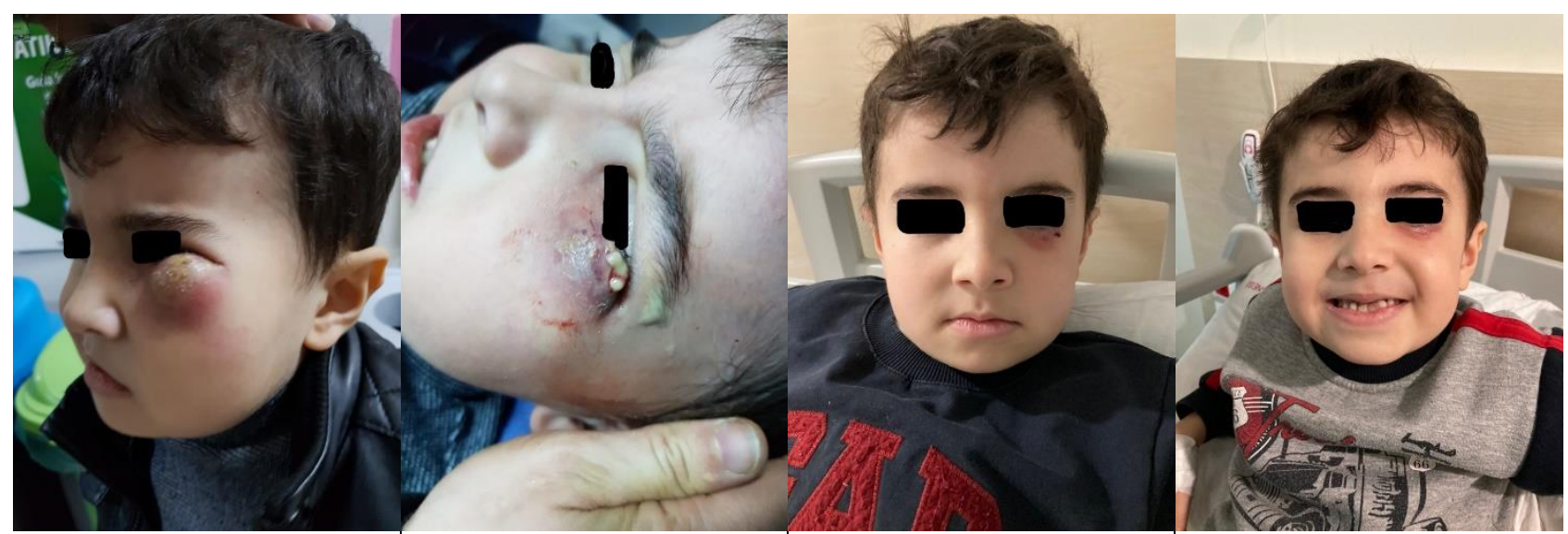

Figure 1. Patient's admission

Figure 2. During the drainage

Figure 3. $4^{\text {th }}$ day of treatment

Figure 4. $7^{\text {th }}$ day of treatment 
patients. It was found that most abscesses originated from soft tissue $(n=13)$. Other origins were intra-abdominalperirectal $(n=8)$, pleuropulmonary $(n=7)$, odontogenicneck $(n=2)$, genitourinary $(n=2)$, and the central nervous system $(n=2)$. Compared to other species of SMG, $S$. constellatus can cause a wider range of infections, including odontogenic and intra-abdominal diseases (3). In the study performed by Faden et al. (6) S. constellatus was predominately isolated from perforated acute appendicitis samples. Intra-abdominal abscesses were also found in half of the perforated acute appendicitis cases. Furthermore, S. constellatus was isolated from acute osteomyelitis samples and samples collected from dental abscesses, hand abscesses, and peritonsillar abscesses. However, growth did not occur in blood cultures. $S$. constellatus may sometimes lead to respiratory tract infections, which can cause pleural effusions or abscesses. However, they are easily treatable (7). In rare cases, it may cause bacteremia (2). It has been observed that bacteremia occurs most often after a tooth or soft tissue infection (4). It is presumed that immunocompromised patients, such as those with diabetes mellitus, chronic kidney disease, hepatobiliary disease, neoplasias, or undergoing chemotherapy, are at higher risk of bacteremia (8). Our patient was not immunocompromised. There was no detectable growth in the blood culture.

Adults with thrombosis have been more frequently associated with $S$. constellatus caused head and neck infections than those caused by other SMG members (9). Our patient had no symptoms of thrombosis. However, it is imperative to remain vigilant for complications during patient follow-ups due to the higher risk of thrombosis caused by $S$. constellatus.

Penicillin and cephalosporin are effective treatment options for $S$. constellatus infections. The susceptibility of S. constellatus to tetracycline, clindamycin, or erythromycin is reportedly varied. Antibiotic treatment for pyogenic abscesses should be chosen based on the antibiotic susceptibility test results, along with aspiration and drainage. In cases where the abscesses cannot be drained, penicillin and cephalosporin show promising results in treating $S$. constellatus infections $(3,10)$. We learned that the patient had received amoxicillin-clavulanic acid therapy orally irregularly for two weeks before admission. Upon direct palpation, a purulent discharge from the abscess was observed. The abscess was immediately drained. The patient was then hospitalized, and treatment began with clindamycin and cefoperazone-sulbactam. S. constellatus had grown in the abscess cultures and so the current therapy was changed to ampicillin-sulbactam. On the seventh day of hospitalization, it was observed that the patient's swelling, redness, and tenderness had subsided almost entirely. He was then discharged and advised on treatment and follow-up procedures.

Although $S$. constellatus is not a commonly found species of bacteria, associated infections should be carefully monitored as the likelihood of complications and its pathogenic capacity may be overlooked.
Informed Consent: Written informed consent was obtained from the patient for publication and accompanying images.

Conflict of Interest: None declared by the authors.

Financial Disclosure: None declared by the authors.

Acknowledgements: None declared by the authors.

Author Contributions: Idea/Concept: ÖK, DKİ, AK; Design: ÖK, DKİ, EF, EEU, AK; Data Collection/Processing: ÖK, DKİ, EF, EEU, AK; Analysis/Interpretation: ÖK, DKİ, EF, EEU, AK; Literature Review: ÖK, DKİ, EF, EEU, AK; Drafting/Writing: ÖK, DKİ, EF, EEU, AK; Critical Review: ÖK, DKİ, AK.

\section{REFERENCES}

1. Jacobs JA, Pietersen HG, Stobberingh EE, Soeters PB. Streptococcus anginosus, Streptococcus constellatus and Streptococcus intermedius. Clinical relevance, hemolytic and serologic characteristics. Am J Clin Pathol. 1995;104(5):547-53.

2. Ng KW, Mukhopadhyay A. Streptococcus constellatus bacteremia causing septic shock following tooth extraction: a case report. Cases J. 2009;2:6493.

3. Claridge JE 3rd, Attorri S, Musher DM, Hebert J, Dunbar S. Streptococcus intermedius, Streptococcus constellatus, and Streptococcus anginosus ("Streptococcus milleri group") are of different clinical importance and are not equally associated with abscess. Clin Infect Dis. 2001;32(10):1511-5.

4. Dsouza R, Roopavathana B, Chase S, Nayak S. Streptococcus constellatus: a rare causative agent of pyogenic liver abscess. BMJ Case Rep. 2019;12(12):e229738.

5. Al Asaadi Z, Srinivasan B, Melchers LJ, Brennan PA. Streptococcus constellatus causing bony destruction secondary to odontogenic infection: three rare cases. Br J Oral Maxillofac Surg. 2019;57(6):594-6.

6. Faden H, Mohmand M. Infections associated with Streptococcus constellatus in children. Pediatr Infect Dis J. 2017;36(11):1099-100.

7. Chrastek D, Hickman S, Sitaranjan D, Vokshi I, Kakisi O, Kadlec J, et al. Streptococcus constellatus causing empyema and sepsis, necessitating early surgical decortication. Case Rep Infect Dis. 2020;2020:4630809.

8. Khan MZ, Tahir D, Kichloo A, Haddad N, Hanan A. Pyogenic liver abscess and sepsis caused by Streptococcus constellatus in the immunocompetent host. Cureus. 2020;12(8):e9802.

9. McNeil JC, Dunn JJ, Kaplan SL, Vallejo JG. Complications of otitis media and sinusitis caused by Streptococcus anginosus group organisms in children. Pediatr Infect Dis J. 2020;39(2):108-13.

10. Tracy M, Wanahita A, Shuhatovich Y, Goldsmith EA, Clarridge JE 3rd, Musher DM. Antibiotic susceptibilities of genetically characterized Streptococcus milleri group strains. Antimicrob Agents Chemother. 2001;45(5):1511-4. 